\title{
Baltic visions and dilemmas of territorial defence after 16 years in NATO
}

\author{
Krzystof Zaleski \\ WSB University, \\ Dabrowa Gornica, \\ Poland \\ kzaleski@wsb.edu.pl
}

Zdzislaw Śliwa

Baltic Defence College, Tartu,

University of Tartu, Tartu,

Estonia

Zdzislaw.Sliwa@,baltdefcol.org

\section{Viljar Veebel}

Baltic Defence College, Tartu,

University of Tartu, Tartu, Estonia

Viljar.veebel@baltdefcol.org

ORCID 0000-0002-9122-0134

Abstract. The concepts of development of territorial defence forces and capabilities are different within the North Atlantic Treaty Organization (NATO) and are closely linked with specific characteristics of respective nations. Moreover, it is linked with historic circumstances, culture, composition of society and other specific domains. Changes in the internal and international security environment are further affecting decisions about selecting specific defence and deterrence models. The security on the Eastern Flank of the NATO has progressed visibly after 2014 events in Ukraine, causing investments into Estonian, Latvian and Lithuanian territorial defence as a recognition of their value to support their armed forces. The aim of the current research is to analyse the ongoing evolution of territorial defence forces of three Baltic countries in broader regional perspective in light of changed threat perception and risk assessments.

Keywords: Baltic States, deterrence, territorial defence, North Atlantic Treaty Organization.

JEL Classification: F1, F5, P4

Received:

June, 2020

1st Revision:

October, 2020

Accepted:

December, 2020

DOI:

$10.14254 / 2071-$

$8330.2020 / 13-4 / 13$ 


\section{INTRODUCTION}

In recent decades, military reforms and development in the Baltic States have followed the NATO preferences and assessment system, drawing on the official strategic-level documents of NATO (Veebel and Ploom, 2019). This has been the way to determine what is effective and what contributes best to progress and outcome in terms of sufficient defence and credible deterrence. In practical terms, reforms in the Baltic militaries have mostly been focused on the ability to fit into the solidarity-based deterrence model, to have niche capabilities, to be able to receive allied forces and to assure the local population that the best choices have been made (Veebel, 2018).

While the existing conventional reserves of the NATO member states are sizeable, safe and quick deployment is a critical variable in the event of a conflict scenario in the Baltic States. This might be problematic considering the very limited safe transportation options available in the region. The Baltic States, neighbouring the North-West military district of Russia, are one of the few areas where, compared to NATO's similar needs and options, Russian options in resupplying, logistical support and regrouping of military forces are very promising, especially concerning safety and alternative logistical options. The Russian advantage could actually be even growing, should Russia believe that there exists a winning regional strategy for a conflict with NATO, and focuses on rapid improvement of its anti-access/area denial capabilities near the Baltic borders (Veebel 2019; Mykhailyshyn, 2017).

The aim of the current study is to present the evolution of three Baltic countries' territorial defence forces as the nations on the Eastern Flank of NATO, in the context of regional cooperation and evolving security environment. The central focus of the research is to recognize which are the different solutions and how they support the concepts of national defence of the respective nations. The starting assessment is that such concepts are differing among the nations in NATO, but tasks are overlapping in many fields; what is visibly different regarding subordination and size. In general, territorial units are an important factor to support and complement regular armed forces in specific areas. They create close links with the society by involving various groups of the society, thus providing a source or reserve manpower with at least basic military training.

The following study is composed of three major parts. The first part of the current article focuses on theoretical options and dilemmas for Baltic States in terms of territorial defence and deterrence. In the second part of the study the authors provide an overview of territorial defence forces of Estonia, Latvia and Lithuania in the context of their background, organization and specific characteristics, including their tasks ranging from peace, crisis to wartime. This is leading to the analytical part of the study which is presenting findings and conclusions and allowing drawing deductions in general terms related to the presented concepts of territorial defence.

\section{THEORETICAL OPTIONS FOR BALTIC STATES WHEN CHOOSING TERRITORIAL DEFENCE MODEL}

The concepts of creating territorial defence type forces (TDF) are neither new nor exclusively linked with the current century, as throughout history they have had very important role in defence of territory of many nations involving the broad range of societal groups. They were closely linked with overall concepts of national defence or just ad-hoc voluntary groups related to resilience and resistance against aggression and later on to fight occupation forces. Such the units, formal or informal in nature, were operating often in a region from which their members were coming from; therefore they were fighting for local societies, own households and families. It was supporting motivation and dedication to act decisively. Such examples, when population was actively involved in guerrilla warfare were presented in history e.g. by resistance of Spanish and Russian people against Napoleon troops invasion or later Russian resistance against fascists 
(German) occupation. In China and Vietnam the forces founded based on population decisively supported the victory against conventional, better-trained, and equipped operational units from Japan and U.S. respectively. In Poland, the German occupation was faced by continuous resistance thorough all the war period and it was continued against communists' government as of lack of acceptance for new ideology and subordination to Soviet Russia. However, the territorial defence forces are not only prepared for guerrilla warfare, as those training is closely linked with preparing them to support operation of regular armed forces as light type units. Conceptually, the term 'territorial defence' in every nation means something different and it "evokes different memories and it has multifaceted political, organizational and strategic connotations" (Roberts, 1976, 34). Finland has extensive experiences in this aspect as the national defence planning that initially the enemy will face the resistance of local force to hinder attack by attacking flanks and lines of communication (Tillotson, 1993, 276). Such the partisans' tactics could be effectively utilized when terrain and local conditions will support it. The delay operations and wearing down enemy troops is allowing denying seizing key terrain and infrastructure and in the long-term, it is creating supportive conditions for counterattack by friendly armed forces. In Ukraine, so-called volunteer battalions provided initial response to counter separatist units, at the same time they exposed the weakness of armed forces being not ready to deliver required united reaction to the aggression. They played significant role during the first phase of the war in 2014 and later they were transferred into national territory defence battalions or paramilitary organizations, and many were included into land forces.

Theoretically, TDF could be divided into three categories (Makar and Novoskoltseva, 2016; Rieker 2002, 21-38) The first one is based on armed forces model ready to execute combat missions with them or to be send abroad (U.S., Germany, and United Kingdom). The second group is presented by small nations with the main task to protect and defend critical objects facilitating mobilization of regular armed forces, their operational deployment and manoeuvre (Baltic countries of Estonia, Latvia and Lithuania, Norway, Denmark, and Belgium). Finally, the third category belongs to neutral nations with the broad range of tasks, including guerrilla warfare in the case of occupation (Finland, Sweden, and Switzerland).The tasks and organization of units within the categories mentioned above are differing during peace, crisis and war and quite often, those are overlapping. The point is that there are many tasks related to support for local communities e.g. as of facing consequences of natural disasters. Such the need caused allocation of proper resources, which were not adequate to requirements in the past and not properly allocated as of lack of clear priorities. It was recognition of the need to involve population much stronger into defence matters and lack of personal reserves as of cancelling conscription. In the context of role of TDF in response to non-military or 'hybrid' threats, the topic is very often mentioned after 2014. According to Ryszard Jakubczak it is purposeful as:

„The only approach to weaken the effectiveness of aggressors in conducting hybrid operations is the properly developed territorial defence system, because TDF formations can be widely deployed at the local level and could operate strategically based on principles typical for unified command while maintaining a large dose of autonomy at the local level" (Jakubczak, 2016, 42).

He is also concluding that those units should not be subordinated to regular operational units and those should a separate service of armed forces, such the model is present in Poland.

Michael Clemmesen (2000) has recognized that the territorial defence is not preferred option; the more effective is stopping an aggressor before entering a territory of a country; however, such the option is not always achievable for relatively small nations when facing stronger opponents. In Estonia when considering possible defence scenarios already at the beginning of independence it was decided to build forces, which would allow defending sovereignty and continuous resistance in the case of occupation (Laaneots, 2000, 
94). Similar approach has been undertaken in Lithuania and Latvia. All the nations have been continuing those processes successively adjusting forces and capabilities to evolution and changes in their security environment. In that context it is worth to mention that even Russia decided in 2016 to create National Guard after analysing this type of forces in other nations and based on own historical experiences.

\section{MAIN ASPECTS OF NATIONAL DEFENCE MODELS OF THE BALTIC STATES}

Considering the fact that the three Baltic States are attempting to protect themselves against the same potential threat - possible aggression $\mathrm{n}$ from the Russian side - and are hoping for the same allies from the EU and NATO, it is definitely intriguing that they seem to have chosen different approaches in developing their respective national defence models (Veebel and Ploom, 2018). However, it should be noted that these three countries do not constitute pure examples of fundamentally different approaches when choosing between a professional army and a conscription service.

Although the potential threats from Russia are similar for Estonia, Latvia, and Lithuania, the countries have adopted different national defence models. While Estonia has followed a total defence approach with a strong focus on territorial defence, a compulsory military service and a reservist army, Latvia has opted for a solely professional army with a considerably smaller amount of supporting manpower, and Lithuania has used a mixed system (Veebel and Ploom, 2019). As far as discussing the security choices of a small country bordering an aggressive and resurgent neighbour is concerned, the Estonian and Latvian defence models constitute a particularly intriguing pair while Lithuania represents a compromise between them.

After the restoration of independence in 1991, NATO membership and the principle of collective defence based on Article 5 of the North Atlantic Treaty became the main foreign policy objectives for the Baltic States, as local political elites were convinced that the Organization would have a pivotal and strategic role in strengthening their independence and sovereignty, as well as in confronting potential existential threats from the Russian side. NATO membership, combined with EU accession, was also strongly supported by the public. After successful reforms and relatively smooth accession negotiations, all three countries joined NATO in 2004. Paradoxically, this main strategic achievement left the Baltic States without a clear long-term vision of what should be the future goal of the countries' security and defence policies. This is mainly because over the decade when the Baltic States were preparing to join NATO, the Alliance transformed. The same applies to the visions and perceptions of the organization (and of the so-called Western world as a whole) towards Russia. During this time, NATO repositioned itself from an organization committed to the principle of collective defence to a multi-tasking body dealing with issues beyond the original collective defence, e.g. anti-terrorism activities, peacekeeping missions, and crisis management. Similarly, in the early 2000s Russia was rather considered as a partner, not as an adversary (Veebel and Ploom, 2018). Thus, in 2004 the Baltic States did not, in fact, join the same organization that they were expecting to join in the early 1990s, i.e. an organization with a primary focus on the principle of collective defence, as well as an organization with the capability and willingness to defend its member states in response to a military attack by an external party.

Both the systematic development of the national defence forces, and the debates on national security guarantees, are clearly driven in all three Baltic countries by the fear of potential Russian aggression (Veebel 2017). In the event of a conventional conflict, the early stage of resilience is mostly based on the local military forces of Estonia, Latvia, or Lithuania. However, Baltic security and defence models have significant limitations with regard to fundamental dilemmas in deterrence. Bearing in mind that all three models are oriented towards guaranteeing territorial defence, the practical question remains whether in real terms they are aimed at: a) defending the geographical territory of countries in order to avoid all possible losses of territory; b) defending the countries' territories to the fullest extent possible, but also accepting some losses; 
or c) providing sufficient deterrence to avoid any attack. From the perspective of the armed forces, the preferred option would surely be the third one; however, the credibility of the current models to provide reliable deterrence is questionable. None of the Estonian, Latvian and Lithuanian defence models consist of independent retaliation capabilities, which would tempt Russia to opt for painless testing-risking (Veebel, 2019).

\section{TERRITORIAL DEFENCE FORCES IN BALTIC STATES}

The nations of Estonia, Latvia and Lithuania are possessing traditions related to voluntary formations and those are coming from interwar period and the period after restoring independence at the beginning of nineties of the pervious century. This is linked with their small size and population and the character of military capabilities, as those nations and land forces heavy and in reality, they do not possess air and navy components of armed forces. Therefore, the effort of the whole society is critical to create abilities to resist any aggression. The three nations are not able to defend their sovereignty alone and this is why the membership in NATO and European Union (EU) became one of priorities of their foreign policy. It is not only exclusively about those two important international organizations as strategic partnership with United States of America and support for transatlantic links has played an important role for all of them based on understanding of this nations capabilities to deter threats against them, especially coming from Russian Federation. It was recognized when President Obama visited Tallinn in 2014 stating, the "defence of Tallinn and Riga and Vilnius is just as important as the defence of Berlin and Paris and London" (Obama 2014). President Trump when talking about those nations recognized their quick raise of military budget to $2 \%$ (Estonia already in 2015 and Latvia, Lithuania in 2018), which was one of lead topics for him during NATO summits. The nations has created close partnership with U.S. National Guard as follows Estonia - Maryland, Lithuania - Pennsylvania, Latvia - Michigan, to strengthen relations and to exchange experiences when building own structures. The cooperation with other nations, including newly created Poland's Territorial Defence Forces, was followed (Ploom, Sliwa and Veebel, 2020).

Table 1

Armed forces and territorial defence forces of Estonia, Lithuania and Latvia (2018)

\begin{tabular}{|c|c|c|c|}
\hline & Estonia & Lithuania & Latvia \\
\hline Population & $1.3 \mathrm{mln}$ & $2.75 \mathrm{mln}$ & $1.9 \mathrm{mln}$ \\
\hline GDP (2018) USD & $30 \mathrm{bn} 285 \mathrm{mln}$ & $53 \mathrm{bn} 251 \mathrm{mln}$ & 34bn $849 \mathrm{mln}$ \\
\hline $\begin{array}{l}\text { Military budget (2018) } \\
\text { USD }\end{array}$ & $\begin{array}{c}2.14 \% \text { GDP } \\
618 \mathrm{mln}\end{array}$ & $\begin{array}{c}2.00 \% \text { GDP } \\
1 \mathrm{bn} 30 \mathrm{mln}\end{array}$ & $\begin{array}{c}2.03 \% \text { GDP } \\
636 \mathrm{mln}\end{array}$ \\
\hline Armed forces & 6600 troops & 19,850 troops & 6000 troops \\
\hline Conscription & Yes & $\begin{array}{l}\text { Cancelled in 2008, } \\
\text { restored in } 2015\end{array}$ & No \\
\hline $\begin{array}{l}\text { Participation in } \\
\text { missions abroad }\end{array}$ & Yes & Yes & Yes \\
\hline $\begin{array}{l}\text { Territorial Defence } \\
\text { Forces }\end{array}$ & $\begin{array}{l}16000 \text { members (26000 with } \\
\text { subordinated organizations ) }\end{array}$ & $\begin{array}{l}4500 \text { volunteers and } 500 \\
\text { active duty soldiers }\end{array}$ & $\begin{array}{c}8300 \text { members } \\
\text { (including } 600 \text { active } \\
\text { duty soldiers) }\end{array}$ \\
\hline $\begin{array}{l}\text { Number of districts of } \\
\text { TDF }\end{array}$ & $\begin{array}{l}4 \text { defence commands (15 } \\
\text { regional commands) }\end{array}$ & 6 regional commands & 4 regional brigades \\
\hline
\end{tabular}

Source: The Heritage Foundation 2019; Kozłowski 2019, The World Bank 2019 and SIPRI 2019.

The territorial defence forces are playing very important role in those nations however, their structure, subordination, tasks are different in nature, and it is connected with their specific characteristics. In those nations 'TDF are viewed as one of the elements in the national defence systems' response during the early 
stages of a hybrid conflict. The Baltic states have decided to adapt their Territorial Defence Forces to new threats by making a number of changes to their functioning, depending on the local conditions in each case" (Szymanski, 2015). The basic data about armed forces and territorial defence forces of Estonia, Lithuania and Latvia are presented in table1.

As presented the concepts and adopted models are differing when taking into account proportion of population/armed forces/TDF or conscription and reserve soldiers. Next, real funds as those are linked with their GDP not allowing making procurement of specific capabilities (navy, air force). What is uniting them is clear understanding of the role of developing national military power and requirement to dedicate proper resources although not in united and coordinated way. The research report of the think-tank RAND Corporation, which is including in the title such words as 'resilience' and 'resistance', is assessing the capabilities of the three Baltic countries to conduct total defence and unconventional warfare (Flanagan, 2019). It is highlighting the role of the latter when conducting by territorial defence forces as a factor supporting deterrence toward potential aggressor. This is connected with cost-effect calculus to be taken under consideration by potential occupant. This is very clear that Baltic nations have connected their security and future with NATO and EU and it was rational choice. Nevertheless, all of them are developing national capabilities, reinforcing combat power within available resources and funds. In the case of the worst scenario (conventional aggression), they will still rely on combat potential of allies, especially U.S. as of possessed strategic deployment abilities allowing to move troops and equipment in short notice. Such the abilities are limitation for many European allies possessing only operational deployment potential.

\subsection{Estonia - Defence League}

Estonian Defence League (EDL) (Est. Kaitseliit) was initially established as self-defence organization on 11 November 1918; however, after Soviet occupation in 1940 it was disbanded. With the renewed independence it was reactivated in 1990; what is significant 18 months before formal announcement of Estonian sovereignty. Therefore, it is the organization with longstanding historical traditions causing it to be deeply rooted in societal mind-set and this is triggering wide support for its membership and activities. One of effects is the presence in the EDL's structure voluntary associations: 'Women's Voluntary Defence Organization' (Est. Naiskodukaitse), the girl scout organisation 'Home Daughters' (Est. Kodutütred) or scout type patriotic youth paramilitary organization 'Young Eagles' (Est. Noored Kotkad). The first one is receiving medical training, field catering, and basic military training. The last two are not defence organizations but their volunteers have independent programme they follow and it is not linked to military ones. Their role is rather to develop patriotic and national spirit.

„The Estonian Defence League Act” (Estonian Parliament 2016) regulates legal status of the Estonian Defence League and its role in defending the independence of Estonia and its constitutional order and ensuring safety of citizens. The membership in EDL is voluntary but for many citizens it is a matter of pride and honour to be among ranks. Such the prestige is presented by the fact that to be accepted as a member, the recommendations from two active EDL members are required and every member is paying small voluntary contributions. The organization is voluntary and independent and it has its own collegial bodies, which are exercising the management and control of the organization personnel, budget and resources. Nevertheless, the Commander of the EDL is directly subordinated to the Estonian Chief of Defence, who has authority to command the troops/units composed of EDL members, which are assigned to Estonian Defence Forces (EDF) during wartime structures via Commander of EDL. The total number of EDL members is estimated to be 16000 and with the support associations is counts some 26000 organized in 15 regional commands (malevs), which are organized in 4 regional defence commands (Estonian Defence League 2019). Estimated Estonian wartime structure is as many as 25000 and reserve pool is estimated to 
reach 60000 men. The regionalization is allowing conducting operations in the well-known terrain during peace, crisis and war; the advantage is that the natural environment and urban terrain are supporting unconventional operations by trained and properly equipped troops. The estimated budget of EDL counts some $8 \%$ of the overall military budget and such the funds dedicated to this formation are growing during last years. It is mainly spend for EDF personnel costs, peacetime operations and maintenance, limited infrastructure construction and training. It does not include major investments to the weapon, ammunition and equipment, since that part of budget belongs to EDF.

The important characteristic of EDL is the permission of possessing weapon by its members at their homes, but after completing medical check and training concluded by an exam, next it is connected with the requirement to participate in military type exercises, including those with regular units of armed forces. The EDL units were a matter of 'snap mobilizations' and those presented very high level of appearance of their soldiers - reaching $85 \%$ and more (Glinska, 2018). The social character is influencing the wide range of tasks and those are typical military assignments as Host Nation Support (HNS), irregular warfare and partisan type operations, sabotage and counter mobility. Moreover, it is about creating pro-defence and patriotic attitude of society, improving members' skills by continuous trainings and exercises, support for local administration for crisis management tasks, protection of public order and security of key infrastructure (Malysa, 2017). The further development of EDL is ongoing and according to National Defence Action Plan 2019-2022' the finance will secure “equipping of 6 new Defence League territorial defence companies" and in 2022 " 6 light infantry companies will have been added to the significantly more mobile 4 battalions of the territorial defence structure of the Defence League". These units are part of defence forces wartime structure by they are manned and trained by EDL. Next, the financial resources will increase, among others to continue and enhance patriotic education, to conduct additional recruitment as of the need for more intensive activities. It will be supported by the EDL School, which is possessing personnel and infrastructure for training that will be more intensive in coming years. Such the complex and well-concerned decisions are connected with the desire to equalize the potential of armed forces and EDL, extend membership and to lower reaction time in the case mobilization. In February 2019, the Ministry of Defence approved 2020-2023 development plan showing continuing investment into EDL by "increase to $€ 43$ million per year, in addition to investments to be made in the equipment of Kaitseliit-based territorial defence units"; it is to be achieved until 2023 (Vahtla, 2019). This is highly required as the total number of members is planned to reach some 30000 in 2022 requiring investment into their training, equipment and participation in exercises (Flanagan, 2019). It could be assumed that EDL has been and will be playing significant role within the national defence concept being credible and powerful constituent of Estonian ability to defend itself and to facilitate deployment of friendly forces during crisis time to fight together. In the case of occupation, it will have potential to conduct resistance as it was in the past.

\subsection{Lithuania - National Defence Volunteer Forces}

Lithuanian National Defence Volunteer Forces (NDVF) were activated on 17 January 1991 immediately after the country regained its independence along with legal framework. It was just formal recognition of voluntary forces, which had been functioning already in 1990. They have been further authorized by the „Republic of Lithuania Law on the Organisation of the National Defence System and Military Service" (Lithuanian National Defence Forces 2019) allowing their continuous development and appointing leadership and forming new units. At the beginning, NDVF had been independent; however, in 2003 they were subordinated to Lithuanian Land Forces. The membership in NATO in 2004 marked extension of tasks as next to those related to national defence they started to be responsible for training of reserve soldiers. The task was unique and important especially when Lithuania decided to abolished 
conscription in 2008; but in 2015, the Seimas has decided to return conscription and the task belongs now to every unit including NDVF. Other tasks are equally important including Host Nation Support, preserving high-level combat readiness, participation in missions abroad and support for national local administration during peace and crisis. The reach toward society is supported by organizing seminars and educative campaigns cultivating patriotic consciousness and by strengthening military-society relations between armed forces and local communities. NDVF tasks are additionally adjusted to specific conditions and infrastructure of respective areas of responsibilities. The total number of NDVF is estimated to be some 5400 members, including 4900 volunteers and 500 active duty officers and non-commissioned officers and the latter are covering major leadership and command posts. Volunteers are obliged to participate in the three-month basic military training to continue later by some $20-50$ days of military training per year.

The organization of NDVF is based on six territorial units covering the entire territory of Lithuania. Legitimately, the country approved the law regulating rules of engagement sanctioning use weapon during peacetime; it was based on experiences coming from Ukraine war and invasion of so-called little green men". Such the proactive approach to face non-military threats was important to speedup reaction of military and voluntary forces in cases of e.g. provocations, attacks of armed groups, crossing border by armed people or in general toward facing unconventional threats (Lithuanian Ministry of Defence 2014). NDVF are credible constituent of national defence capabilities as the research among its members in 2015 presented the pride to be a member and very high level of motivation to defend the country $(81 \%$ of positive answers); it was direct reaction for evolving security situation in the Lithuanian neighbourhood (Vileikiene, Pociene and Alekneviciene, 2015). The organization is planning further investment into pro-defence education, including such the education as mandatory subject in schools and discussion about the matter is ongoing. If it will be implemented it will further make NDVF cadre closer to society allowing to continue increasing patriotic spirit among young generation.

It is important to mention that NDVF are cooperating with paramilitary organization the Lithuanian Riflemen's Union (LRU) (Lit. Lietuvos Šaulių Sajunga), which is significant force counting some 11000 volunteers. Parallel, those are trained reserve manpower having capacity to join armed forces or NDVF and to contribute to defence of the country or to continue resistance in the case of occupation. The last aspect is very important as historically Lithuanian partisans (Lit. Lietuvospartizanai) proved to be very effective fighting communists' regime until 1953. Organizationally LRU is structured into ten regions, which are composed of light infantry type companies. The advantage is that part of duties is toward extended cooperation with local communities and possession of variety of specific abilities of members as those are coming from many groups of Lithuanian society. The NDVF and Riflemen Union are not competing organizations, as both have their own niche to contribute to enhance national security. Therefore, those are supplementary organisations marked by good cooperation and relationship. It is worth to mention that preparations of society are multidimensional and example is development and distribution of "Guide to Active Resistance" in 2016 prepared in cooperation with armed forces and the Riflemen's Union (Lithuanian Guerilla Warfare Manual, 2016). It includes guidance for society how to behave in the case of occupation to preserve resilience and to support resistance.

NDVF is continuing and intensifying cooperation with territorial defence forces of Estonia and Latvia based on understanding sharing common operational space. Important are constant relations with Pennsylvania Army National Guard based on special agreement including availability of additional resources to NDVF. The newly established cooperation with Polish Territorial Defence Forces (Pol. Wojska Obrony Terytorialnej - WOT) is another respect of cross boundary relations, as WOT Commander Major General Kukula highlighted "Poland has created it based on Lithuanian experiences" (Lapszewicz 2019; Moldovan, 2018). Signing cooperation agreement between NDVF and WOT has been an important prove of such the 
relations. Therefore, both organizations' contribution to multilateral cooperation within the region is supporting defence concepts based on common perception of threats.

\subsection{Latvian National Guard}

Latvian National Guard (LNG) (Lat.: Zemessardze) has been created on 23 August 1991 and the legal status was approved on 06 April 1993 by the Act "On the National Guard of the Republic of Latvia" (The Supreme Council of Latvia 2003) and it was one of the first laws of the newly independent country. Currently LNG is directly subordinated to Latvian Chief of Defence as one of services. This solution is positively supporting integration with regular units of armed forces and inclusion into national defence plan as part of land forces. 'The State Defence Concept 2012' defines the LNG ,as the main NAF reserve base that is being developed by attracting reserve soldiers and reservists and involving them in public self-defence" and it is facilitating active involvement of the whole society into national defence (Latvian Parliament, 2012). This is parallel enhancing close links between society and armed forces. The main tasks within national defence system are:

- Support to other regular force units of the NAF by maintaining the required specialised capabilities including Host Nation Support;

- Support for collective defence by participating in international operations;

- Full integration and interoperability with other NAF regular force units, building very close cooperation with the Land Forces Infantry Brigade in training and exercising, and in international operations.

There is an important role of LNG in maintaining properly working mobilization system, support for law enforcement forces to uphold respect to national law and finally provision of critical infrastructure security. The main leadership positions in the LNG are manned by professional military and there are some 8300 members in the organization including 600 active duty soldiers. Within the structure, there are four regional brigades and those are composed on infantry battalions; additionally directly subordinated to the Commander of the LNG are cyber defence unit and psychological support platoon. Some brigades are already possessing engineering and logistics battalions and air defence companies supporting their independence in operations. As areas of operations are linked with the terrain from which volunteers are originating there is very close link between local population and respective units. Such the volunteers are signing a contract, usually for five years, and it is mandatory for them to have minimum twenty-one days of basic training during first year to be continued later. A specific characteristic in Latvia is formation of quick reaction platoons and companies being ready to react especially in the case of 'hybrid' type threats e.g. socalled 'little green man' but also to support local administration in the case of local social unrest; it is based on experiences from Ukraine.

The development of LNG was impacted by financial crisis 2007- 2008 causing drastically cut of funds and some active duty cadre left armed forces; the result were visible in following years. The state audit in 2015 presented many shortcomings as ineffective training, lack of common standards, unclear registration system and some others (Andžāns and Veebel, 2017). It was important as the attention was given back to LNG in the context of growing threat from Russia and its 'compatriot policy', allowing improving the recognition of guardsmen, their status and capabilities. It was supported by 'State Defence Concept 2016', which highlighted the role of the National Guard and the Young Guards in strengthening civil society stating, "National Defence is unconditional. Every citizen's duty is to defend the country and [...] resist the aggressor" (Nikers, 2016). The document raised number of armed forces up to 17500 men including 6500 professional soldiers, 8000 National Guard troops and 3000 reserve soldiers. For that reason some 70mln Euro were dedicated to further develop 18 increased readiness LNG units, equipping them with "air 
defence, anti-tank, sniper, engineering, weapons of mass destruction, mortar and engineering capabilities" (Rostoks and Vanaga, 2016). Next, there was decision to implement Youth Guard Development Programme 2015-2024 aiming to increase membership from 6000 up to 16000 by promoting patriotic spirit among young generation. The process of investment is ongoing and LNG is under constant development with positive perspectives as it is planned to raise the total number up to 12000 in 2027 along with investments into weapon systems, equipment and infrastructure allowing to make more intensive program of exercises and integration with regular units (Flanagan 2019). To legalize such the long-term vision Latvia is developing 'State Defence Concept 2020', which is to preserve the intent to continue development of professional and stronger LNG (Latvian Ministry of Defence 2019).

Considering the fact that the three Baltic States are attempting to protect themselves against the same potential threat - possible aggression from the Russian side - and are hoping for the same allies from the EU and NATO, it is definitely intriguing that they seem to have chosen different approaches in developing their respective national defence models. However, it should be noted that these three countries do not constitute pure examples of fundamentally different approaches when choosing between a professional army and a conscription service. Although the potential threats from Russia are similar for Estonia, Latvia, and Lithuania, the countries have adopted different national defence models. While Estonia has followed a total defence approach with a strong focus on territorial defence, a compulsory military service and a reservist army, Latvia has opted for a solely professional army with a considerably smaller amount of supporting manpower, and Lithuania has used a mixed system. As far as discussing the security choices of a small country bordering an aggressive and resurgent neighbour is concerned, the Estonian and Latvian defence models constitute a particularly intriguing pair while Lithuania represents a compromise between them.

\section{CONCLUSION}

It is undisputable that territorial defence forces are extremely important constituents of the defence systems of all the Baltic countries and it is based on the assessment of the security threats. Those are similar and the 2014 annexation of Crimea proved to be a warning message for them impacting decisions to invest in that type of forces following the NATO Article 3 obligations (NATO 2018). In this context TDF are contributing to deterrence factor including their role in shaping patriotic spirit among citizens of those nations contributing to enhancement of resilience and resistance in the case of war and occupation. The study recognized however that there are significant differences among those three nations related to their concepts of TDF including subordination, command and control, structure, capabilities and some dissimilarities related to tasks. When considering just ratio between number of population and TDF members the best situation is in Estonia (not even counting support associations). Nevertheless, all the nations are investing in this type of units and there is growing recognition of the need of closer international cooperation as in the case of war national borders are not playing any role for aggressor. Beneficial was signing cooperation agreement among Estonian Defence League, National Defence Volunteer Force and Latvian National Guard in January 2016 facilitating yearly "staff consultations where chiefs of staffs of the Baltic States' volunteer forces discuss combat training, sports and cultural cooperation for the following year" (Lithuanian Defence Forces 2016). It included partnership of selected TDF units and decision about extending programs of exercises including cross border ones. The cooperation is growing and it will be continued, as in the past nations were focused on itself; the 2014 events in Ukraine has changed the situation for better (Shvedun, 2018). The new situation is supporting familiarization with each other, exchange of data (although there are some national limitations in this aspect), assistance in crisis and mutual support 
during war. In this context, all the formations are possessing expertise, capabilities and equipment that could be used to contribute to neighbouring actions nation when required.

The similar for those nations is readiness to face non-military threats and there are already laws in place allowing such the quick an independent reaction at lower levels of chain of command (in all nations, especially Latvia and Lithuania). Next, TDF are supporting mobilization during war, the challenge is of course response time; therefore, their constant readiness is critical, as reaction time in the case of military aggression will be limited. Their role is additionally related to building reserve capabilities based on training of their members and volunteers and it is regulated by national laws allowing releasing them for such duties by companies. Parallel, TDF are strengthening the link between society and armed force. As volunteers are coming from all groups of societies and are possessing variety of personal and professional skills their roles could be enhanced beyond outcome of regular training based on their initiatives and imagination. As TDF are voluntary the motivation and readiness to dedicate their fate to national defence is very high, nevertheless it must be sustained by proper education and shaping pro-patriotic spirit. It is important as e.g. Latvia and Estonia are aiming to raise number of members significantly. The modern societies are evolving and threat perception is changing. For example in Estonia, the threat "an extensive or limited military attack against Estonia" in October 2018 was recognized among respondents as the seventh one (20\% positive answers; rather improbable 47\%; completely improbable 24\%)(Kivirähk, 2018). The top threats were cyber-attack, 'fake news' and interference in "Estonian politics or economy in order to influence these in their own interests". The perception of threat in Latvia and Lithuania ids differing as Russia is recognized as the main threat for independence and territorial integrity.

The nations are distinguishing the changes in combat operations environment; therefore, those are conducting training not only in outer terrain but also in urbanized areas. This is based on current conflicts when conducting unconventional combat but also based on reality of new warfare and technological development causing that former guerrilla way of war has limitations. They are creating new capabilities, like cyber units in Estonia and Latvia or psychological support detachments. The common characteristic are planned investments into enhancing combat power, more intensive exercises with regular units of respective armed forces and procurement of more sophisticated weapon systems, especially anti-tank capabilities taking into account type of forces of potential aggressor. The limitation is however, volunteer character of TDF as their capabilities and combat power could achieve only specific level (Szymański 2015), not comparable with professional soldiers. This is direct outcome of limited time of training and those are not ready to face in combat regular armour and mechanized forces and fully stop them. Next, more advanced systems are requiring more training to operate them and to use them within specific structures and joint operations. It is causing TDF to have specific tactics and ability to perform e.g. delay operations using terrain for their advantage.

Discussing membership, it is necessary to recognize the negative trends like aging populations, competition on labour market, outflow of young people to look for work abroad, lower interest in military or voluntary service are limiting ability to receive members, who are very qualified. Such the trend is visible in many nations and it is causing that many are more interested in civilian jobs, which are often better paid. The situation is similar in all those three nations. The important is close link of TDF with society and local administration supporting creation of patriotic spirit and enhancing interest in defence domain. The Lithuanian drive to include defence education into schools curricula is an example of recognition of such the needs. All those factors are important during peace, crisis and war. During the first two TDF could support locals in daily activities and within crisis or threat of war TDF could monitor situation, secure critical infrastructure and react for local activities of entities supporting potential aggressor. In war, TDF will create the first echelon of defence conducting delay actions, acts of diversion denying enemy freedom of movement and reducing momentum of operations. This is critical for regular armed forces to achieve full 
operational capabilities and this is case of Baltic nations as an attack could be done unexpectedly using one of principles of war - surprise. The latter factor could be a challenge for mobilization for TDF and achieving full readiness to fight in their structures. This is the case if Russia would decide to make 'snap' aggression within limited time and without clearly recognized warnings and indicators. The large-scale exercises could be used to camouflage for such an action. It is not highly probable, but it should not be completely excluded, as the situation on the NATO Eastern Flank has been fragile since 2014. Estonia, Latvia are especially fragile bordering Russia; Lithuania and Poland are in slightly better situation as of bordering Belarus, so any major deployment of troops to this country could be a signal to rise readiness of TDF and armed forces.

Although conceptually the models of three Baltic nations are differing, their role is very similar connected with ability to conduct operations within well-known terrain and in support of local communities. It is facilitated by growing cross border cooperation of Estonian, Latvian and Lithuanian TDF creating unified operational area not divided by borders. The support of regular units is another key aspect. As of ongoing investments, they will play a role to face 'hybrid' challenges although they will not be able to stop powerful land - air aggression. They will not be ready as of limited combat potential and even psychological preparedness; however, they will play a role to preserve resilience and to continue active and passive resistance. This type of forces is very important for small nations as part of deterrence discouraging aggression against their territory and independence. Therefore, evolution of TDF and their doctrinal role will be continued preserving them as credible constituent of national defence capabilities.

\section{ACKNOWLEDGEMENT}

Authors have not received any support or funds to carry out this research.

\section{REFERENCES}

Clemmesen M. (2000). Territorial Defence in Baltic Defence College, The Baltic Defence Review No 3.

Comprehensive National Defence in Latvia, Ministry of Defence, Riga 2019, https://www.mod.gov.lv/sites/mod/files/document/Comprehensive $\% 20$ National $\% 20$ Defence $\% 20$ in $\% 20$ Latvia.docx (accessed: 24 November 2019).

Defence Expenditure of NATO Countries (2012-2019), NATO Brussels 25 June 2019.

Estonian Defence League (2019), http://www.kaitseliit.ee/en/edl (accessed: 20 November 2019).

Estonian Ministry of Defence. (2018) National Defence Action Plan 2019-2022, , Tallinn updated 22 February 2018, http://www.kaitseministeerium.ee/en/objectives-activities/defence-planning/national-defence-actionplan-2019-2022 (accessed: 18 November 2019).

Estonian Parliament. (2014). The Estonian Defence League Act.

Flanagan, S. J. et al. (2019), Deterring Russian Aggression in the Baltic States through Resilience and Resistance, RAND Corporation

Glińska, P. (2018), WOT: qacieśniamy wspótprace z. Estoniq, PolskaZbrojna 18 June 2018, http://www.polskazbroina.pl/home/articleshow/25900?t=WOT-zaciesniamy-wspolprace-z-Estonia- ） (accessed: 15 November2019).

Jakubczak, R. (2016), Wojska Obrony Terytorialnej w sұtuce wojennej, Ante Portas - Studia nadBezpieczeństwem No 2(7), Ostrowiec Świętokrzyski 2016.

Kivirähk, J. (2018), Public Opinion and National Defence, Survey, Ministry of Defence.

Laaneots, A. (2000), The Defence League and Defence Districts, The Baltic Defence Review 3

Lapszewicz, B. (2019). Obchody 28.rocznicy utworæenia Ochotniçych Sit Obrony Kraju, Kurier Wileński 17 January 2019, https://kurierwilenski.lt/2019/01/17/obchody-28-rocznicy-utworzenia-ochotniczych-sil-obrony-kraju/ (accessed: 24 November 2019).

Latvian National Guard. (2019), https://www.zs.mil.lv/en (accessed: 06 November 2019).

Lithuanian Guerrilla Warfare Manual - Translated to English, Breach Bang Clear 02 November 2016, https://www.breachbangclear.com/lithuanian-guerrilla-warfare-manual-translated-to-english/ (accessed: 23 November 2019). 
Lithuanian National Defence Volunteer Forces, http://kariuomene.kam.lt/en/structure 1469/national defence volunteer forces 1357.html (accessed: 24 November 2019).

Lithuanian Parliament. (1999). Republic of Lithuania Law on the Organisation of the National Defence System and Military Service, Sejm, Vilnius 05 May 1998, amendments in 1999.

Makar, Y. (2016), Novoskoltseva L., The Place and Role of Territorial Defence in the National Security System of the Ukrainian State, Ante Portas - Studia nad Bezpieczeństwem No 2 (7), Ostrowiec Świętokrzyski 2016.

Małysa, T. (2017). Wojska obrony terytorialnej w państwach battyckich, Bezpieczeństwo. Teoriai Praktyka No 3/2017.

Ministry of National Defence of Poland. (2017). The Defence Concept of the Republic of Poland.

Moldovan, A. (2018). Poland's National Security Policy in a New Regional Security Environment. Case Study: National Security Strategy of Poland (2014). Torun International Studies, 1(11), 89-102.

Mykhailyshyn, V. (2017). The Influence of the Conflict in Ukraine on the Modernization of the Russian Armed Forces Since 2014. Torun International Studies, 1(10), 39-59. https://dx.doi.org/10.12775/TSM.2017.004

NATO. (2016). The Secretary General's Annual Report 2015. NATO Brussels 2016.

NATO. (2017). Fact sheet: Key NATO \& Allied Exercises. May 2017. https://www.nato.int/nato static fl2014/assets/pdf/pdf 2017 05/20170510 1705factsheet exercises en.pdf

NATO. (2018) Resilience and Article 3, NATO Website, 25 June 2018, https://www.nato.int/cps/en/natohq/topics 132722.htm (accessed: 24 November 2019).

Nikers, O. (2016), Inside Latvia's New State Defense Concept: Riga Declares Its Military Ambitions Ahead of NATO Summit, Eurasia Daily Monitor Volume: 13 Issue: 104, Jamestown Foundation 28 May 2016.

Obama B. (2014). Tallinn speech in full: NATO will defend Estonia, Latvia, Lithuania, DELFI.ee 03 September 2014 , https:/ / www.delfi.ee/archive/barack-obama-tallinn-speech-in-full-nato-will-defend-estonia-latvialithuania?id=69666267 (accessed: 19 November 2019).

Ploom, I., Sliwa, Z., \& Veebel, V. (2020). The NATO "Defender 2020" exercise in the Baltic States: Will measured escalation lead to credible deterrence or provoke an escalation?. Comparative Strategy, 39(4), 368-384. doi:10.1080/01495933.2020.1772626

Rieker P. (2002). From territorial defence to comprehensive security? European integration and the changing Norwegian and Swedish security identities, Norwegian Institute of International Affairs, Oslo March 2002.

Roberts, A. (1976). Nations in Arms, The Theory \& Practice of Territorial Defence, The International Institute for Strategic Studies, London.

Rostoks, T., \& Vanaga, N. (2016). Latvia’s Security and Defence Post-2014. Journal on Baltic Security, 2(2).

Shvedun, V. (2018). Interstate Reforms of Ukraine in the Context of its Interaction with NATO. Torun International Studies, 1(11), 37-46. https://doi.org/10.12775/TIS.2018.003.

SIPRI. (2019). Military Expenditure Database, Military expenditure by country, in constant (2017) US\$ m., 1988-2018, SIPRI 2019.

Szymański, P (2015). The Baltic states' Territorial Defence Forces in the face of bybrid threats, Commentaries OSW No 16519 March 2015, Centre for Eastern Studies (OSW), Warsaw 2015.

The Heritage Foundation. (2019). 2020 Index of Military Strength. Assessment Environment. Europe.

The State Defence Concept, Confirmed by the Cabinet of Ministers of the Republic of Latvia on 20 April 2012 Approved by the Saeima (Parliament) on 10 May 2012, Riga.

The Supreme Council of the Republic of Latvia. (2003). On the National Guard of the Republic of Latvia, , 1993, with amendments from 1994, 1996, 1997, 2000, 2002 and 2003.

The World Bank (2019). https://data.worldbank.org/indicator/NY.GDP.PCAP.CD?locations=LT-UA-LV-EE (accessed: 10 November 2019).

Tillotson, H. M. (1993). Finland at Peace \& War 1918 - 1993, Russell Publishing Ltd, Norwich 1993.

Vahtla, A. (2019). Ministry of Defence approves 2020-2023 development plan, Baltic News Service.

Veebel, V. (2017). Russia's Neo-Imperial dependence model: Experiences of former Soviet republics. Romanian Journal of Political Science, 17 (1), 4-34.

Veebel, V. (2018). NATO options and dilemmas for deterring Russia in the Baltic States. Defence Studies, 18(2).

Veebel, V. (2019). Why it would be strategically rational for Russia to escalate in Kaliningrad and the Suwalki corridor. Comparative Strategy, 38(3), 182-197, doi:10.1080/01495933.2019.1606659

Veebel, V., \& Ploom, I. (2018). The Deterrence Credibility of NATO and the Readiness of the Baltic States to Employ the Deterrence Instruments. Lithuanian Annual Strategic Review, 16(1).

Veebel, V., \& Ploom, I. (2019). Are the Baltic States and NATO on the right path in deterring Russia in the Baltic?, Defense \& Security Analysis, 35(4), 406-422, doi:10.1080/14751798.2019.1675947

Vileikiene, E., Pociene, A., \& Alekneviciene, J. (2015). Analysis of Volunteer Soldiers' Attitudes to Service in the Lithuanian Military, Lithuanian Annual Strategic Review 2014-2015, 13. 